\title{
Menopozal Dönemdeki Kadınlarda Huzursuz Bacak Sendromunun Görülme Sıklı̆̆ı, Yaşam ve Uyku Kalitesi Üzerine Etkisi
}

\author{
Prevalence and Effect of Restless Legs Syndrome on Quality of Life and \\ Sleep Quality in Menopausal Women
}

\author{
Hamide ALTUNDAĞ $\breve{a}^{\mathrm{a}}$ Sevil ŞAHİN
}

ÖZ Amaç: Araştırma, menopozal dönemdeki kadınlarda Huzursuz Bacak Sendromunun (HBS) görülme sıklığı, yaşam ve uyku kalitesi üzerine etkisini belirlemek amacı ile kesitsel ve analitik bir çalışma olarak planlanmıştır. Gereç ve Yöntemler: Araştırmanın örneklemini Menopoz Polikliniğine başvuran ve HBS'li olan 256 ile HBS'li olmayan 359 menopoz dönemindeki toplam 615 kadın oluşturmuştur. Veri toplama aracı olarak, "Bireysel Bilgi Formu", "Huzursuz Bacak Sendromu Tanı Kriterleri", "Huzursuz Bacak Sendromu-Şiddet Değerlendirme Ölçeği", "Pittsburgh Uyku Kalitesi İndeksi", "SF-36 Yaşam Kalitesi Ölçeği" kullanılmıştır. Bulgular: Araştırmaya katılan kadınların yaş ortalaması 53.72 \pm 5.92 yıl olup, \%50.4'ünün HBS'li olduğu ve \%46.8'inin ise HBS'li olmadığı belirlenmiş̧ir. Araştırmada HBS'li olan ve HBS'li olmayan grup karşılaştırıldığında; HBS farkındalığı, ailede HBS tanısı ve ailede HBS olan bireyler yönünden gruplar arasında istatistiksel olarak anlamlı farklar olduğu ortaya çıkmıştır ( $\mathrm{p}<0.05$ ). HBS'li olan kadınların \%96.1'inin ve HBS'liolmayankadınların \%88'inin menopozda sağlık sorunları yaşadıkları ve bu sorunların çoğunluğunun sıcak basması sorunu olduğu belirlenmiştir. HBS'li olan ve olmayan iki grup Pittsburg Uyku Kalitesi İndeksi Ölçeği puanları açısından karşılaştıııldığında uyku kalitesi, öznel uyku kalitesi, uyku latensi, uyku süresi, alışılmış uyku etkinliği ve uyku bozukluğu alt ölçek puanları HBS'li olan grupta istatistiksel anlamlılık düzeyinde daha kötü olduğu belirlenmiştir $(\mathrm{p}<0.05)$. Benzer şekilde HBS'li olmayan kadınların yaşam kalitesinin HBS'li olanlara göre daha iyi olduğu belirlenmiştir $(\mathrm{p}<0.05)$. Sonuç: HBS yaşam ve uyku kalitesini olumsuz etkileyen ve uyku bozukluklarının ayırıcı tanısında akılda tutulması gereken klinik bir durumdur. Bu nedenle prevalansının tespiti için daha geniş örneklemli toplum tabanlı çalışmalara ağırlık verilmesi ve bu konuda hemşirelerin uzmanlaşarak aktif rol almaları önerilmektedir.

Anahtar Kelimeler: Huzursuz bacak sendromu, menopoz, uyku kalitesi, yaşam kalitesi

\begin{abstract}
Aim: This is a cross-sectional and analytical study to determine prevalence and effect of the Restless Legs Syndrome (RLS) on quality of life and sleep quality in menopausal women. Materials and Metods: Study sample consisted of a total of 615 menopausal women presented to the Menopause Polyclinic, including 256 women with RLS and 359 women without RLS. Data collection instruments included "Personal Information Form", "Restless Legs Syndrome Diagnostic Criteria", "Restless Legs Syndrome Rating Scale", "Pittsburgh Sleep Quality Index" (PSQI) and "SF-36 Health-Related Quality of Life Survey". One-Sample Kolmogorov-Smirnov test was used for pre-assessment of data. Result: Women in the study had a mean age of 53.72 \pm 5.92 years. Out of these women, $50.4 \%$ had RLS and $46.8 \%$ had no RLS. Comparison of groups with RLS and without RLS revealed statistically significant differences between the groups in terms of RLS awareness, diagnosis of RLS in the family and family members with RLS ( $\mathrm{p}<0.05$ ). It was determined that $96.1 \%$ of women with RLS and $88 \%$ of women without RLS experienced health issues, particularly hot flush, during the menopause. Both groups were compared in terms of Pittsburgh Sleep Quality Index scores and it was found out that the group with RLS had statistically significant lower scores in sleep quality, subjective sleep quality, sleep latency, sleep duration, habitual sleep efficiency and sleep disturbance subscales $(\mathrm{p}<0.05)$. Similarly, it was determined that quality of life of women
\end{abstract}

Geliş Tarihi/Received: 28-03-2018 / Kabul Tarihi/Accepted: 20-07-2018

${ }^{a}$ Uzm. Hemş. Zekai Tahir Burak Kadın Sağlığı Eğitim ve Araştırma Hastanesi,e-posta:hamidealtundag@ gmail.com ORCID: 0000-0002-6989-5880

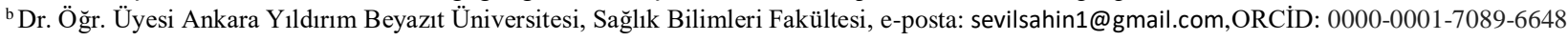

Sorumlu yazar/Correspondence: Dr. Öğr. Üyesi Sevil Şahin, Ankara Yıldırım Beyazıt Üniversitesi, Sağlık Bilimleri Fakültesi, e-posta: sevilsahin1@gmail.com

* Bu çalışma Yüksek lisans tezinden üretilmiştir. Ankara Yıldırım Beyazıt Üniversitesi, Sağlık Bilimler Enstitüsü Yüksek Lisans tezi, 2017.

** Bu çalışma, International Metting on Education\&Research in HealthScience (IMER-HS), Istanbul, Turkey, 3-5 November 2017, kongrede sözlü sunum olarak sunulmuştur.

Atıf:Altundă̆ H, Şahin S. Menopozal dönemdeki kadınlarda huzursuz bacak sendromunun görülme sıklığı, yaşam ve uyku kalitesi üzerine etkisi. Sağlık Bilimleri ve Meslekleri Dergisi 2019;6(1):62-73

Citation: Altundağ H, Şahin S. Prevalence and effect of restless legs syndrome on quality of life and sleep quality in menopausal women Journal of Health Science and Profession 2019;6(1): 62-73

HSP 2019;6(1):62-73 
without RLS was better than those with RLS ( $\mathrm{p}<0.05)$. Conclusion:There stless legs syndrome is a clinical condition that affects quality of life and sleep quality adversely and it must be considered in differential diagnosis of sleep disorders. Therefore, community-based studies must be conducted on a larger sample to determine its prevalence and it is recommended that nurses must specialize in this condition to take an active role.

Keywords : Menopaus, restless legs syndrome, e, sleep quality, quality of life.

\section{Giriş}

Overlerin foliküler aktivitelerini yitirmesi sonucu menstruasyonun kalic1 olarak sonlaması menopoz olarak tanımlanır (1). Menopoz sözcüğü, Yunanca Mens (ay) ve pause (durmak) sözcüklerinden türetilmiştir. Dünya genelinde eski çağlardan bu yana görülme yaşının ırksal özelliklerle ve çevresel faktörlerle değişmediği kabul edilmekte ve 45-55 yaş olarak bildirilmektedir (1). Türkiye'de yapılan bazı çalışmalarda ise menopoza girme yaşının 45 ile 50 arasında değiştiği bildirilmektedir $(2,3)$. Türkiye nüfus sağlık araştırmaları 2013 sonuçlarına göre Türkiye' de 48-49 yaşlarındaki kadınların \%49.1'inin postmenopozal dönemde olduğu bildirilmektedir (4). Bu da kadınların yaşam süreçlerinin üçte birini menopoz ve menopoz sorunlarıyla geçirmesi anlamına gelmektedir $(1,2,5)$.

İnsan yaşamında bebeklik, çocukluk, ergenlik, yetişkinlik dönemlerinin kendine özgü fiziki ve duygusal özellikleri olduğu gibi menopoz dönemi de kendine özgü özellikler içerir. Bu dönem kadınlarda yaşlılığa geçişin en önemli başlangıç noktasıdır. Çünkü menopoz; hormon dengesinin değişmesi sonucu overlerden androjen hariç steroidlerin salgılanmasının azalması, östrojen yapımının yavaş yavaş azalarak amenoreye varması ile oluşur. Buna bağlı olarak kadınların $\% 50$ 'sinde psikolojik, fizyolojik ve davranışsal değişiklikler görülmekte, beden ve ruh sağlığı değişmektedir. Beden sağlığının etkilenmesi ile bazı hastalıklara karşı çok daha duyarlı olma arasında güçlü bir ilişki bulunmaktadır. $\mathrm{Bu}$ hastalıklardan biri de Huzursuz Bacak Sendromudur (HBS) (5).

HBS ilk kez 1685 y1lında Thomas Willis tarafindan tanımlanmıştır (6). Ekbom tarafindan 1945 yllında huzursuz bacak sendromu'nun ilk vaka bildirimi yapılmıştır (7). HBS; akşamları ve çoğunlukla geceleri artan, hareketle azalan, dinlenmekle kötüleşen, bacaklarda daha şiddetli olmak üzere ekstremitelerde şiddetli, hoşa gitmeyen, sevimsiz duyularm (parestezi ve dizestezi vb.) olduğu sensorimotor bir bozukluktur. Semptomlar genellikle bacaklarda, nadiren de kollarda, iki taraflı, simetrik, çoğunlukla geceleri oluşur ve uzun süreli hareketsizlik durumlarında kötüleşip, hareket ile düzelir (8).

Yapılan araştırma sonuçlarına göre, toplumda huzursuz bacak sendromunun görülme sıklığ 1 ortalama \%10-15 arasında değişmektedir $(4,9)$. HBS semptomları ile doktora başvuran hastaların çoğu orta ve ileri yaştadır. Ancak olguların \%35-45'inde şikayetler 20 yaş öncesinde başlamaktadır $(10,11)$. Yapılan başka bir çalışmada ise HBS semptomlarının ortalama başlangıç yaşının 27 olduğu ancak hastaların \%13'ünde semptomların 10 yaşından önce ortaya çıktığ 1 belirtilmiştir (9). HBS'nin herhangi bir yaşta başlayabildiği fakat patofizyolojik mekanizmaları halen açık olmasa da, kadın cinsiyetin hastalık için bir risk faktörü olduğu belirtilmektedir. Epidemiyolojik çalışmaların çoğunda HBS'nin kadınlarda yaklaşık 2 kat daha sık görüldügü bildirilmiştir (1214).

HBS'nin toplumlar arasindaki prevelans farkının; genetik, etnik, coğrafi faktörler, beslenme gibi nedenlerden mi kaynaklandiğ 1 tam olarak bilinmemektedir. HBS'nin sık görülmesine rağmen hastalar tarafindan yeterince ifade edilmemesi, ayıric1 tanisinin yapilamaması ve hekimler tarafından az bilinmesi nedenleri ile HBS teşhis edilememektedir. Hakkında çok daha fazla bilgiye ihtiyaç duyulan bu hastalığın menopozal dönemde olan kadınlardaki etkilerinin belirlenmesi oldukça önemlidir.

Hastalığın etyopatogenezi tam olarak henüz ortaya konulamamış olsa da, hastaların dopaminerjik tedaviye olumlu cevap vermesi hastalığın santral sinir sistemi kökenli dopamin ve demir azlığına bağlı olabileceğini düşündürmüştür. HBS ile uyku bozuklukları ve yaşam kalitesi arasında yakın bir ilişki olduğu bilinmektedir $(13,14)$. Araştırmalar HBS'nin uykuyu, kognitif fonksiyonları ve yaşam kalitesini olumsuz yönde etkilediği göstermiş olup medikal tedaviyi gerektirecek kadar rahatsızlık verici olduğu tespit 
edilmiştir (14-16). Ayrıca menopoz dönemindeki bir kadının uyku kalitesi onun yaşam kalitesini de etkiler. Uyku kalitesi; uyku latensi, uyku süresi ve bir gecedeki uyanma sayısı gibi uykunun niceliksel yönlerini ve uykunun derinliği, dinlendiriciliği gibi daha öznel yönleri içerir. Toplumda erişkin bireylerin \%15-35'inde uykuya dalma ve uykuyu sürdürme güçlüğü gibi uyku kalitesini ilgilendiren bozuklukları bulunmaktadır $(15,16)$. Menopozal dönemdeki kadına hizmet veren hemşirelerin bu dönemdeki kadınlarında uyku ve yaşam kalitesinin nelerden etkilenebileceğini bilmesi, bireyin yaşı, eğitim düzeyi, medeni durumu, çocuk sayıs1, menopoz, kronik hastalık durumu gibi özelliklerini değerlendirerek bireysel hemşirelik bakımı ve danışmanlık sunması önemlidir $(15,16)$. Bu bağlamda menopoz döneminde HBS'nin görülme sıklığının yaşam ve uyku kalitesi üzerine herhangi bir etkisinin olup olmadığının araştırılması literatüre yeni kaynaklar eklemek adına katkı sağlayacaktır.

$\mathrm{Bu}$ araştırma, menopozal dönemdeki kadınlarda HBS'nin görülme sıklığı, yaşam ve uyku kalitesi üzerine etkisini belirlemek amacı ile planlanmıştır.

\section{Gereç ve Yöntemler}

\section{Araştırmanın Evreni ve Örneklemi}

Kesitsel ve analitik tipte araştırmanın evrenini, Temmuz 2015-Temmuz 2016 tarihleri arasında bir devlet hastanesinde menopoz polikliniğine başvuran menopoz dönemindeki tüm kadınlar oluşturdu. Araştırmanın örneklemine $\% 95$ güven ve 0.05 duyarlılıkla hesaplanarak en az birey sayıs 400 olarak saptanmıştır. Araştırmanın örneklemine bir yıl süreyle menstruasyon görmeyerek doğal yolla menopoza girmiş olan, Total Abdominal Histerekomi (TAH-BSO) yapılarak cerrahi yolla menopoza girmiş olan, 65 yaşı aşmamış olan, işitsel veya zihinsel bir engeli olmayan, iletişime ve işbirliğine açık, çalışmaya katılmaya istekli ve yazılı onamları olan 615 kadın örnekleme dahil edilmiştir.

\section{Veri Toplama Araçları}

Araştırmacı tarafından literatür bilgilerine uygun hazırlanan (5-10, 15-20) Bireysel Bilgi Formu, Huzursuz Bacak Sendromu Tan1 Kriterleri, Huzursuz Bacak Sendromu-Şiddet Değerlendirme Ölçeği, Pittsburg Uyku Kalitesi Ölçeği, SF-36
Yaşam Kalitesi Ölçeği olmak üzere toplam beş form kullanılmıştır.

Bireysel Bilgi Formu: iki bölümden oluşmaktadır. Birinci bölüm; bireysel özelliklere ilişkin (yaş, eğitim durumu, meslek, medeni durum, ekonomik durum algisı vb.) sorulardan, İkinci bölüm; genel tıbbı öyküye ilişkin (sürekli hastalık ve ilaç kullanma durumu) ve menopoza ilişkin (menopoz yaş1 ve şekli, menopoz döneminde yaşanılan sağlık sorunlar1, menopoz algis1, menopoz döneminde aile ve yakinlardan destek alma durumu vb.) sorudan oluşmaktadır.

Huzursuz Bacak Sendromu Tanı Kriterleri: Uluslararası Huzursuz Bacak Sendromu çalışma Grubu (IRLSSG International Restless Legs Syndrome Study Group= IRLSSG), tarafindan 1995 yılında tanı için gerekli kriterler ve genellikle görülen özellikler belirlenmiştir. Ulusal Sağlık Enstitüsü Konferansı sırasinda aralarında IRLSSG üyeleri ve epidemiyoloji ve ölçek tasarımı otoritelerinin bulunduğu uzmanlar 2002 Mayıs ayında bu kriterleri netleştirerek tekrar düzenlemişlerdir. "Amerikan Ulusal Sağlık Enstitüsü (National Institues of Health=NIH)" tarafindan tanı standardizasyonu için 2003 y1lında tekrar düzenlenmiştir. Günümüzde halen tanıda bu kriterler kullanılmaktadır $(17,18)$. Huzursuz Bacak Sendromu tanısı klinik sorgulama ve değerlendirmeye dayanmaktadır. Ancak gerekli durumlarda laboratuvar ve görüntüleme yöntemlerinden yararlanılabilinmektedir. Hastalarda nörolojik muayene sıklıkla normaldir. Kesin tanı için dört temel kriterin hepsinin karşılanması gerekmektedir.

1) Uzuvlarda (özellikle bacaklarda) ortaya çıkan hoşa gitmeyen hisler ya da rahatsızlık hissi ile birlikte hareket ettirme isteği olması,

2) Hoşa gitmeyen hisler ya da hareket ettirme isteğinin yatma ya da oturma gibi hareketsizlik dönemleri sırasında başlaması ya da kötüleşmesi,

3) Hoşa gitmeyen hisler veya hareket ettirme isteğinin yürüme, ovalama, sallama gibi hareketlerle en azından aktivite devam ettiği sürece kısmen veya tamamen iyileşmesi,

4) Semptomların akşam veya geceleri gündüze göre daha kötü olması ya da akşam/geceleri ortaya çıkması (18). 
Huzursuz Bacak Sendromu Şiddet Değerlendirme Ölçeği: HBS derecelendirme skalasında, temel özelliklerin subjektif değerlendirilmesi (skalanın 1' den 3'e kadarki soruları), hastalığın şiddeti ve siklığı (skalanın 7 ve 8 . soruları) ve bağlantılı uyku problemleri (skalanın 4 . ve 5. soruları) gösterilmiştir. Skala aynı zamanda semptomların hastaların ruhsal durumu ve günlük işlevleri üzerindeki etkilerini araştıran soruları da içermektedir (skalanın 9. ve 10. soruları). HBS derecelendirme skalası, 10 sorudan oluşmaktadır. Her bir sorudaki HBS şiddet değerleri, HBS'nin etkisi olmaması (0 puan) ya da çok şiddetli HBS (4 puan) olarak derecelendirilmektedir. Böylece tüm skor aralığında 0 ve 40 arasında değişen bir toplam skor elde edilmektedir $(17,18)$. IRLSSG şiddet skalasında değerlendirme; 0-10 puan hafif, 11-20 puan orta, 21-30 puan şiddetli, 31-40 puan çok şiddetli HBS olarak yapılmaktadır (19).

Pittsburgh Uyku Kalitesi İndeksi (PUKI): Uyku kalitesi indeksi, 1989 yılında Buysse ve arkadaşları tarafından geliştirilmiştir. Türkiye' de geçerlilik ve güvenirlik çalışması 1996 yılında Ağargün ve arkadaşları tarafından yapılmış olup iç tutarlılık katsayıs1 0.80 olarak bildirilmiştir (20). Araştırmada ölçeğin Cronbach Alpha değeri 0.80 olarak bulunmuştur.

SF-36 Yaşam Kalitesi Ölçeği: SF-36 yaşam kalitesini ölçmede kullanılan en yaygın jenerik ölçütlerden biridir. Ware tarafindan 1987 yılında geliştirilen SF-36 sağlığın hem pozitif, hem negatif yönlerini ölçmek için toplam 36 sorudan oluşan klinik uygulama ve araştırmalarda, genel popülasyon incelemelerinde kullanılmak üzere düzenlenmiş bir ölçektir (21). Türkçe'ye Koçyiğit tarafindan çevrilmiş, geçerlilik ve güvenilirlik çalışması yapılmıştır. Ölçeğin ön test-son test güvenilirliğgi 0.94 , iç tutarlılığ 0.92 'dir. Araştırma kapsamında yapılan iç tutarlık analizi sonrasında ölçeğin Cronbach Alpha değeri 0.89 olarak bulunmuştur. SF-36 Yaşam Kalitesi Ölçeği, 36 soru maddesi içermekte olup, 8 alt boyuta sahiptir. Ölçeğin fiziksel fonksiyon alt boyutu 10 soru, fiziksel-rol sınırlamaları alt boyutu 4 soru, ağrı alt boyutu 2 soru, genel sağlık algisı alt boyutu 5 soru, enerji ve zindelik alt boyutu 4 soru, sosyal fonksiyonellik alt boyutu 2 soru, mental-rol alt boyutu 3 soru, ruh sağlığ 1 alt boyutu beş soru içermektedir. Ölçekten alınabilecek en düşük puan
0 , en yüksek puan ise 100 olup, puan arttıkça yaşam kalitesinin de arttığı düşünülmektedir $(21,22)$.

\section{Araştırmanın Etik Boyutu}

Araştırmanın uygulanması için Yıldırım Beyazıt Üniversitesi Etik Kurulu'ndan, araştırmanın uygulama alanı olan Zekai Tahir Burak Kadın Sağlığı Eğitim ve Araştırma Hastanesi Eğitim Planlama Kurulundan gerekli izinler alınmıştır. Anket formu uygulanmadan önce bireylere araştırmanın amacı ve formun içeriği hakkında açıklamalarda bulunup, katılımları için onam formunu okumaları ve onaylamaları istenmişstir.

\section{Araştırmanın Uygulanması}

Veri toplama formlarının (Bireysel Bilgi Formu, Huzursuz Bacak Sendromu Tanı Kriterleri, Huzursuz Bacak Sendromu-Şiddet Değerlendirme Ölçeği, Pittsburg Uyku Kalitesi İndeksi, SF-36 Yaşam Kalitesi Ölç̧eği) anlaşılabilirliği ve uygularken algıda değişiklik varlığının saptanabilmesi amaciyla araştırma kriterlerine uygun 50 kadına ulaşılarak ön uygulama yapılmıştır. Ön uygulama sonrasında herhangi bir problem ile karşılaşılmamış ve bu grup gerçek uygulamaya dahil edilmemiştir. Araştırmada veri toplama formları araştırmacının kendisi tarafindan yüz yüze uygulanmıştır. Veri toplama sürecinde, araştırmaya katılmayı kabul eden her kadın için uygulama süresi esnek tutulmuştur.

\section{Verilerin Değerlendirilmesi}

$\mathrm{Bu}$ çalışmada elde edilen veriler SPSS 20 paket programı aracılığı ile analiz edilmiştir. Araştırmada gruplanan verilerin gerekli istatistiksel analizleri için frekans ve yüzde (\%) değerler ile değişkenlerin birbirinden bağımsızlığını sınamak için Ki-Kare testi yapılmıştır. Araştırmada parametrik ya da nonparametrik hangi test türünün uygulanmas1 hususunda verilerin homojenitesini değerlendirmek için verilere One Sample KolmogorovSmirnov Test uygulanmış, test sonuçları $\mathrm{p}<0.05$ olduğu için nonparametrik test uygulaması kuralına göre, değişkenler incelenmiştir. Verilerin normallik testleri sonucunda iki gruplu karşılaştırmalarda Mann-Whitney $U$ testi kullanılmıştır. İstatistiki analizlerde anlamlılık düzeyi $\mathrm{p}<0.05$ olarak belirlenmiştir.

\section{Bulgular}

Tablo 1'de HBS olan/olmayan kadınların bazı 
sosyo-demografik özelliklerinin dağılımı yer almaktadır. Çalışmamızda araştırmaya katılan 256 kadın (\%41.6) HBS tanı kriterlerini karşılarken, 359 kadın (\%58.4) HBS tanı kriterlerini karşılamamaktadır. Araştırmaya katılan kadınların yaş ortalamasının $53.72 \pm 5.92$ y1l olduğu belirlenmiştir.

Tablo 2'de HBS'li olan/olmayan kadınların HBS farkındalıkları ve ailede HBS tanılarına göre dağılımı yer almaktadır. Çalışmaya katılan HBS'li kadınların \%78'inin, HBS'li olmayan kadınların \% 61.5'inin HBS'yi bilmedikleri belirlenmiştir. $\mathrm{Bu}$ durum HBS farkındalığı boyutunda istatistiksel olarak anlaml bir farka neden olmuştur $(\mathrm{p}<0.05)$. Bir diğer istatistiksel olarak anlamlı $(\mathrm{p}<0.05)$ bulgu ise HBS tanıs1 olan kadınların \%88.7'sinin ailesinde HBS tanısinin olmas1, ailesinde HBS tanıs1 olan kadınların da çoğunluğunun (\%63) annesinde bu

Tablo 1. Huzursuz Bacak Sendromu Olan/Olmayan Kadınların Bazı Bazı Sosyo-Demografik Özeliklerinin Dağılımı

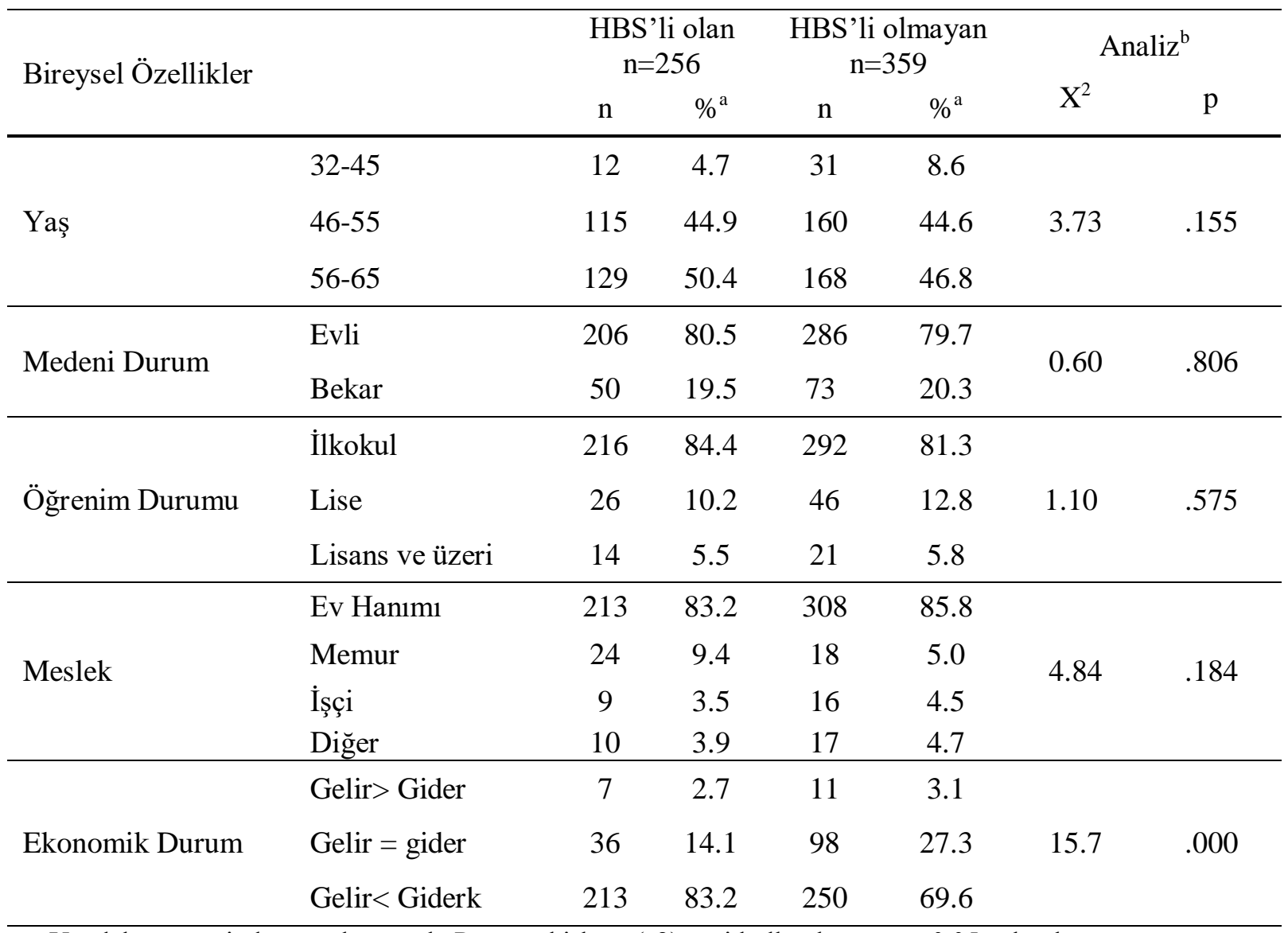

a. Yüzdeler n üzerinden yapılmıştır. b. Pearson ki-kare $(\chi 2)$ testi kullanılııştır, $\mathrm{p}<0.05$ anlamlı

tanının bulunmasıdır. Özetle çalışmada, HBS farkındalığı, ailede HBS tanısı ve ailede HBS olan bireyler yönünden gruplar arasinda istatistiksel olarak anlamlı fark olduğu ortaya çıkmıştır $(\mathrm{p}<0.05)$.

Tablo 3'te HBS'li olan/olmayan kadınların bazı alışkanlıklarına göre dağılımı yer almaktadır.
Kadınların, sigara (tane/gün) ile kahve (fincan/gün) kullanımları ve spor yapma durumlarının dağılımı incelenmiş olup kadınların çoğunun (HBS'li olan \%77.3, HBS'li olmayan \%84.4) sigara kullanmadığı belirlenmiştir. Çalışmada kadınların (HBS'li olan \%55.4 ve HBS'li olmayan \%71.2) günde 1-10 tane sigara içtiği ortaya çıkmıştır $(\mathrm{p}>0.05)$. 
Tablo 2. HBS'li Olan/Olmayan Kadınların HBS Farkındalıkları ve Ailede HBS Tanılarına Göre Dağılımı

\begin{tabular}{|c|c|c|c|c|c|c|c|}
\hline \multirow[t]{2}{*}{ HBS Durumu } & & \multicolumn{2}{|c|}{$\begin{array}{l}\text { HBS'li Olan } \\
\mathrm{n}=256\end{array}$} & \multicolumn{2}{|c|}{$\begin{array}{c}\begin{array}{c}\text { HBS'li olmayan } \\
\mathrm{n}=359\end{array}\end{array}$} & \multicolumn{2}{|c|}{ Analiz $^{b}$} \\
\hline & & $\mathrm{n}$ & $\%^{a}$ & $\mathrm{n}$ & $\%^{\mathrm{a}}$ & $X^{2}$ & $\mathrm{p}$ \\
\hline \multirow[t]{2}{*}{ HBS Farkındalığı } & Evet & 57 & 22.0 & 64 & 47.4 & 8.56 & .002 \\
\hline & Hayır & 199 & 78.0 & 295 & 61.5 & & \\
\hline \multirow[t]{2}{*}{ Ailede HBS tanıs1 olan } & Evet & 29 & 11.3 & 74 & 56.3 & 4.93 & .016 \\
\hline & Hayır & 227 & 88.7 & 285 & 67.9 & & \\
\hline \multirow{4}{*}{$\begin{array}{l}\begin{array}{l}\text { Ailede } \\
(n=103)\end{array}\end{array}$} & Anne & 17 & 63 & 18 & 23.5 & 11.0 & .012 \\
\hline & Baba & 3 & 7.4 & 13 & 18.8 & & \\
\hline & Kardeş & 3 & 7.4 & 21 & 32.4 & & \\
\hline & Diğer & 6 & 22.2 & 22 & 35.3 & & \\
\hline
\end{tabular}

a. Yüzdeler n üzerinden yapılmıştır. b. Pearson ki-kare $(\chi 2)$ testi kullanılmıştır, $p<0.05$ anlamlı.

Tablo 3. HBS'li Olan/Olmayan Kadınların Bazı Alışkanlıklarına Göre Dağılımı

\begin{tabular}{|c|c|c|c|c|c|c|c|}
\hline \multirow[t]{2}{*}{ Değişkenler } & & \multicolumn{2}{|c|}{$\begin{array}{c}\text { HBS'li olan } \\
n=256\end{array}$} & \multicolumn{2}{|c|}{$\begin{array}{c}\text { HBS'li olmayan } \\
\text { n=359 }\end{array}$} & \multicolumn{2}{|c|}{ Analiz $^{\mathrm{b}}$} \\
\hline & & $\mathrm{n}$ & $\%^{\mathrm{a}}$ & $\mathrm{n}$ & $\%^{\mathrm{a}}$ & $X^{2}$ & $\mathrm{p}$ \\
\hline \multirow{2}{*}{ Sigara Kullanımı } & Evet & 58 & 22.7 & 56 & 15.6 & \multirow{2}{*}{4.929} & \multirow{2}{*}{.018} \\
\hline & Hayır & 198 & 77.3 & 303 & 84.4 & & \\
\hline \multirow{3}{*}{$\begin{array}{l}\text { Sigara Sayıs1 * } \\
\text { (Tane/ Gün) }\end{array}$} & $1-10$ & 31 & 55.4 & 42 & 71.2 & \multirow{3}{*}{6.326} & \multirow{3}{*}{.042} \\
\hline & $11-20$ & 23 & 41.1 & 12 & 20.3 & & \\
\hline & 21 ve üzeri & 4 & 3.6 & 5 & 8.5 & & \\
\hline \multirow{2}{*}{ Kahve Tüketimi } & Evet & 84 & 32.8 & 112 & 31.2 & \multirow{2}{*}{0.179} & \multirow{2}{*}{.368} \\
\hline & Hayır & 172 & 67.2 & 247 & 68.8 & & \\
\hline \multirow{3}{*}{$\begin{array}{l}\text { Kahve Sayısı * } \\
\text { (Fincan/ Gün) }\end{array}$} & $1-3$ & 66 & 79.1 & 101 & 89.4 & \multirow{3}{*}{4.055} & \multirow{3}{*}{.132} \\
\hline & $4-5$ & 15 & 17.4 & 10 & 8.8 & & \\
\hline & 5 ve üzeri & 3 & 3.5 & 2 & 1.8 & & \\
\hline \multirow{2}{*}{ Spor Yapma } & Evet & 82 & 32 & 124 & 34.5 & \multirow{2}{*}{.422} & \multirow{2}{*}{.287} \\
\hline & Hayır & 174 & 68 & 235 & 65.5 & & \\
\hline
\end{tabular}

a. Yüzdeler n üzerinden yapılmıştır. b. Pearson ki-kare $(\chi 2)$ testi kullanılmıştır, $\mathrm{p}<0.05$ anlamlı. ${ }^{*}$ n'ler sigara ve kahve içenler üzerinden alınmıştır.

Çalışmaya katılan kadınların yarısına yakınının (\%43.8) HBS semptomları şiddetliyken, \%33.2'si orta, \%20.7'si çok şiddetli ve sadece \%2.3'ünün hafif skorlara sahip olduğu, 
yinekadınların \%57.2'sinin kötü uyku kalitesine, $\% 42.8$ 'inin iyi olarak nitelendirilen uyku kalitesine sahip olduğu belirlenmiştir.

Tablo 4'de HBS'li olan/olmayan kadınların Pittsburgh Uyku Kalitesi İndeksi ortalama puanlarının dağılımı verilmiştir. Tablo incelendiğinde, HBS'li olan kadınların Pittsburgh Uyku Kalitesi İndeksi'nden elde ettikleri puanların

ortalamalarının (8.11 \pm 3.90$)$, HBS'li olmayan kadınlara (6.01 \pm 6.86$)$ göre daha yüksek olduğu

Tablo 4. HBS'li Olan/Olmayan Kadınların Pittsburgh Uyku Kalitesi İndeksi Ortalama Puanlarının ve HBS'li Kadınların HBS Şiddetine Göre Uyku Kalitesi Puanlarının Dağılımı

\begin{tabular}{|c|c|c|c|c|c|c|}
\hline \multirow{2}{*}{ Parametreler } & \multicolumn{2}{|c|}{$\begin{array}{c}\text { HBS'li olan } \\
\mathrm{n}=256\end{array}$} & \multicolumn{2}{|c|}{$\begin{array}{c}\text { HBS'li olmayan } \\
n=359\end{array}$} & \multicolumn{2}{|c|}{ Analiz $^{\mathrm{a}}$} \\
\hline & $\mathrm{X} \pm \mathrm{SS}$ & Min-Max & $\mathrm{X} \pm \mathrm{SS}$ & $\begin{array}{l}\text { Min- } \\
\text { Max }\end{array}$ & $\mathrm{U}$ & $\mathrm{p}$ \\
\hline $\begin{array}{l}\text { Pittsburgh Uyku } \\
\text { Kalitesi İndeksi }\end{array}$ & $8.11 \pm 3.9$ & $1-5$ & $6.01 \pm 6.8$ & $1-5$ & 283 & 0.00 \\
\hline \multirow[t]{2}{*}{$\begin{array}{l}\text { Uyku Kalitesi } \\
\text { Puanları }\end{array}$} & \multicolumn{2}{|c|}{$\begin{array}{l}\text { Toplam Puan } 5 \text { ve alt } \\
n=65\end{array}$} & \multicolumn{2}{|c|}{$\begin{array}{c}\text { Toplam Puan } 5 \text { ve } \\
\text { üzeri } \\
n=191 \\
\end{array}$} & \multicolumn{2}{|c|}{ Analiz $^{\mathrm{b}}$} \\
\hline & $\mathrm{n}$ & $\%^{\mathrm{b}}$ & $\mathrm{n}$ & $\%^{\mathrm{b}}$ & $X^{2}$ & $\mathrm{p}$ \\
\hline \multicolumn{7}{|l|}{$\begin{array}{l}\text { HBS Şiddet } \\
\text { Değerlendirme } \\
\text { Ölçeği Sonuçları }\end{array}$} \\
\hline Hafif & 1 & 1.5 & 5 & 2.6 & 29.77 & .000 \\
\hline Orta & 38 & 58.5 & 45 & 23.6 & & \\
\hline Şiddetli & 22 & 33.8 & 91 & 47.6 & & \\
\hline Çok Șiddetli & 4 & 6.2 & 50 & 26.2 & & \\
\hline
\end{tabular}

a.MannWhitney U testi kullanılmıştır, b: Pearson ki-kare $(\chi 2)$ testi kullanılımışır, $\mathrm{p}<0.05$ anlamlı.

Tablo 5. HBS'li olan/olmayan kadınların Yaşam Kalitesi Ölçeği Ortalama Puanlarının Dağılımı

\begin{tabular}{|c|c|c|c|c|c|c|}
\hline \multirow{3}{*}{$\begin{array}{l}\text { Yaşam Kalitesi } \\
\text { Ölçeği Puanı }\end{array}$} & \multicolumn{2}{|c|}{$\begin{array}{c}\text { HBS'li olan } \\
n=256\end{array}$} & \multicolumn{2}{|c|}{$\begin{array}{c}\begin{array}{c}\text { HBS'li olmayan } \\
n=359\end{array} \\
\end{array}$} & \multicolumn{2}{|c|}{ Analiz $^{\mathrm{a}}$} \\
\hline & $\mathrm{X} \pm \mathrm{SS}$ & Min-Max & $\mathrm{X} \pm \mathrm{SS}$ & Min-Max & $\mathrm{U}$ & $\mathrm{p}$ \\
\hline & $19 \pm 3.62$ & $1.00-3.00$ & $67.59 \pm 13.09$ & $1.00-3.00$ & .000 & 0.00 \\
\hline
\end{tabular}

a.MannWhitney U testi kullanılmıştır, $\mathrm{p}<0.05$ anlamlı

Tablo 6'de HBS'li olan kadınların Yaşam Kalitesi Ölçeğinden elde ettikleri puan görülmektedir. Ortalamalar arasında gözlenen bu fark istatistiksel olarak anlamlıdır $(\mathrm{p}<0.05)$. Ayrıca HBS'li kadınların hastalık şiddetine göre uyku kalitesi puanlarının dağılımı bakıldığında; bulgulara göre HBS hastalık şiddeti, orta şiddetli grupta olanların (\%58.5) uyku kalitesi diğerlerine göre daha iyidir. Katılımcı kadınların hastalık şiddeti şiddetli grupta olunca (\%47.6) uyku kaliteleri daha kötü olmaktadır. $\mathrm{Bu}$ durum istatistiksel olarak anlamlıdır $(\mathrm{p}<0.05)$. 
fark istatistiksel olarak da anlamlı bir farka neden olmuştur. Başka bir ifadeyle, HBS'li olmayan kadınların yaşam kalitesinin HBS'li olanlara göre daha iyi olduğunu söylemek istatistiksel olarak mümkündür $(\mathrm{p}<0.05)$. Yaşam Kalitesi Ölçeği fiziksel fonksiyon, fiziksel-rol sinırlamaları, ağr1, genel sağlık algısı, enerji ve zindelik, sosyal fonksiyonellik, mental-rol ve ruh sağlığı olmak üzere 8 alt boyuttan oluşmaktadır.

\section{Tartışma}

Çalışmamızda araştırmaya katılan 256 kadın (\%41.6) HBS tanı kriterlerini karş1larken, 359 kadın (\%58.4) HBS tanı kriterlerini karşılamamaktadır. HBS kadın popülasyonda oldukça sık görülen bir rahatsızlıktır. Högl ve arkadaşlarının yaptığı bir çalışmada, kadınlarda prevelans \%9\%14.2 arasında bildirilmiştir (23). Taşdemir ve arkadaşları, 2111 kișinin dahil edildiği çalıșmalarında, HBS'nin kadınlarda erkeklere göre 3.5 kat daha sık görüldüğünü ve prevalansın yaşla birlikte arttığını bildirmișlerdir (24). Calıșmamızda HBS'li $\% 50.4$ ve HBS'li olmayan \%46.8 kadının 56-65 yaş aralığında olduğu ortaya çıkmıştır $(\mathrm{p}>0.05)$. Cho ve arkadaşlarının yaptığı 5000 kişilik prevelans çalışmasında, yaşla birlikte hastalığın arttığı, en fazla 50-59 yaşlarında pik yaptığ belirlemişlerdir (25). Bizim çalışmamızda da katılımcıların yaşları ilerledikçe hastalığa daha sık rastlandığı saptanmıştır. Ayrıca yapılan çalışmalar HBS sıklığının ileri yaşlarda (65 yaş ve üzeri) daha fazla olduğunu göstermektedir $(24,25)$.

Calıșmamıza katılan HBS'li olan kadınların \%78'inin, HBS'li olmayan kadınların \%61.5'inin HBS'yi bilmedikleri belirlenmiştir. Ülkemizde yapılan ve aile hekimlerinin HBS'ye ilişkin bilgi düzeylerinin incelendiği bir çalışmada; aile hekimlerin çoğunluğunun HBS konusunda yeterli bilgisinin olmadığı görülmüştür. Çünkü huzursuz bacak sendromu hala atlanabilen veya yanlış tanı konulabilen bir hastalık durumundadır. Hekimlerin dahi bilgilerinin sınırlı olduğu bir konuda HBS'li hastalar, karakteristik olarak semptomlarını tarif etmekte bile güçlük yaşamaktadırlar (26)). Bu nedenle HBS farkındalığı oldukça düşük bir değerde kalmıştır.

Çalışmamıza katılan ve HBS tanısı olan kadınların \%88.7'sinin ailesinde HBS tanısının olduğu, ailesinde HBS tanısı olan kadınların da çoğunluğunun (\%63) annesinde bu tanının bulunduğu ifade edilmiştir. Deveci ve arkadaşları
HBS saptanan 39 kişinin 23'ünde (\%59) aile öyküsünün mevcut olduğunu belirtmişlerdir (27). Winkelman ve arkadaşları HBS hastalığında kalıtım modelini inceledikleri çalışmalarında; HBS hastalar1 ve bunların birinci derecede akrabalar1 epigenetik olarak araştırılmıştır. $\mathrm{Bu}$ çalışma sonucunda HBS'nin genetik geçişli nedenlerden dolayı da kaynaklandığı tespit edilmiştir (28). Ek olarak Khan ve arkadaşlarının çalışmasında nöropatolojik bir rahatsılik olan HBS'nin demir düzeyinin yeterli olamayışına bağlı olarak ortaya çıktığı ve bu duruma bağlı olarak da dopamin metabolizmasının bozulduğu belirtilmektedir. Tüm bu sürecin ise genetik başlangıçlı olduğu bilinmektedir (29). Çalışmamızda ailesinde HBS olanlarda hastalığın büyük oranda görülmesi ve en çok annede hastalığın görülmesi nedeniyle çalışmamız literatürdeki çalışmalar ile uyumludur.

Çalıșmamıza katılan kadınların yarısına yakınının (\%43.8) HBS semptomları şiddetliyken, $\% 33.2$ 'sinin orta, \%20.7'sinin çok şiddetli ve sadece \%2.3'ünün hafif skorlara sahip olduğu saptanmıştır. Deveci ve arkadaşlarının yapmış olduğu çalışmada HBS saptananlarda semptom şiddeti oranlar1; \%7.7 hafif, \%64.1 orta, \%17.9 şiddetli, \%10.3 ise çok şiddetli şeklinde belirtilmiştir (27). Çalışmamızda kadınların \%57.2'sinin kötü uyku kalitesine sahipken, \%42.8'inin iyi olarak nitelendirilen uyku kalitesine sahip olduğu belirlenmiştir. Çölbay ve arkadaş-larının yaptığ çalışmada da uyku kalitesi bozuk olanlar, HBS'si olmayanlarda \%59.6 iken, HBS'li olanlarda \%79.1 olarak saptanmıştır. Ayrıca HBS varlığına göre uyku kalitesinin dağılımı incelendiğinde; HBS'li olanların uyku kalitesinin HBS'li olmayanlara göre anlamlı düzeyde daha kötü olduğu bulunmuştur (30).

Çalışmamızda HBS'li olan kadınların PUKI'den elde ettikleri puanların ortalamaları (8.11 \pm 3.90$)$ olup, HBS'li olmayan kadınlara (6.01 \pm 6.86$)$ göre daha yüksektir. Ortalamalar arasında gözlenen bu fark istatistiksel olarak da anlamlıdır $(\mathrm{p}<0.05)$. Sonuç olarak, HBS'li olmayan kadınların uyku kalitesinin HBS'li kadınlara göre daha iyi olduğu şeklinde bir sonucun ortaya çıktığını söylemek mümkündür. Kim ve arkadaşlarının yaptığı çalışmada yaşlı popülasyonda HBS olan olgularda, olmayanlara göre uyku kalitesinin daha düşük olduğunu saptamışlardır. Çünkü HBS yoğun hareketlere dolayısıyla da insomnia veya aşırı gündüz uyuklamalarına yol açabilmektedir 
(31). Phillips ve arkadaşları HBS sıklığının değerlendirildiği bir çalışmada; HBS riskine sahip olan hastaların \%52'sinin uyku apne açısından yüksek riske sahip olduğunu belirtmişlerdir. Bunun yanında istenmeyen hareketler nedeniyle gece uyku süresinin kısalması, uykuya dalma süresinin uzaması gibi uyku davranış bozuklukları ile HBS arasında da güçlü birliktelik olduğunu belirtmişlerdir (32). Deveci ve arkadaşları çalışmalarında HBS olanların olmayanlara göre ortalama uyku süresinin daha kısa ve uykuya dalma süresinin daha uzun olduğunu saptamışlardır (27). Allen ve arkadaşlarının yaptığı bir çalışmada, HBS semptomlarının oranı; uykuyla ilişkili semptomlar için \%75 olarak bildirilmiş ve bu çalışmada hastaların \%75'ten fazlası, en az 1 tane uykuyla ilişkili semptom bildirmişlerdir. HBS'nin duyusal ve motor anormalliklerinin sonucunda uykuya dalma problemleri ve yetersiz uyku saati nedeniyle uyku kalitesini bozduğu ve bu durumun gün içindeki aktiviteleri ve yaşam kalitesini olumsuz etkilediğini saptamışlardır (14). Güzel ve arkadaşları tarafından yapılan çalışmada hasta olan ve olmayan gruplar karşılaştırıldığında; uyuşma, yanma, kramp gibi duyusal semptomların hasta grubunda neredeyse iki katı daha sık görüldüğü ve HBS'nin hastalarca tanımlanan çoğu semptomunun uyku kalitesini etkilediği belirtilmiştir (33). Çölbay ve arkadaşlarının yaptığı çalışmada HBS varlığıla beraber uyku kalitesinin anlamlı olarak daha da bozulduğu, uyku latensi ve uyku bozukluğunun arttığı saptanmıștır (30).

Çalışmamızda HBS'li olan kadınların PUKI ölçeğinin alt boyutlarından elde ettikleri puanların ortalamalarının HBS'li olmayanlara göre daha yüksek olduğu görülmektedir. HBS'li olan ve olmayan iki grup PUKI puanları açısından karşılaştırıldığında alt ölçeklerden günlük işlev bozukluğu ve uyku ilacı kullanımı boyutlarında istatistiksel olarak anlamlı farkl1lıklar bulunmamaktadır $(\mathrm{p}>0.05)$. Öznel uyku kalitesi, uyku latensi, uyku süresi, alış1mış uyku etkinliği ve uyku bozukluğu alt ölçek puanları HBS'li olan grupta istatistiksel anlamlılık düzeyinde daha kötüdür $(p<0.05)$. Yapılan başka çalışmalarda da uyku latensi HBS olan hastalarda olmayanlara göre anlamlı olarak daha yüksek bulunmuştur. Uykunun HBS olan hastalarda olmayanlara göre anlamlı olarak daha bozuk ve global skor, HBS olanlarda olmayanlara göre anlamlı olarak daha yüksek olduğu tespit edilmiş olup hastalarda sübjektif uyku kalitesi, uyku süresi, alışılmış uyku etkinliği, gündüz işlev bozukluğu, uyku ilacı kullanma açısından HBS olup olmamasına göre anlamlı farklılık saptanmamıştır (30).

Çalışmamızda elde ettiğimiz bulgulara göre; HBS hastalık şiddeti, orta şiddetli grupta olanların (\%58.5) uyku kalitesi diğerlerine göre daha iyidir. Katılımcı kadınların hastalık şiddeti şiddetli grupta olunca $(\% 47.6)$ uyku kaliteleri daha kötü olmaktadır. $\mathrm{Bu}$ durum istatistiksel olarak anlamlıdır $(\mathrm{p}<0.05)$. Güzel ve arkadaşları tarafından yapılan çalışmada da hastalığa eşlik eden uyku bozukluğu ve periyodik bacak hareketi sıklığına bakılmış ve periyodik bacak hareket-lerinin hastaların \%61.1'inde, uyku bozuk-luğunun ise \%53.7'sinde olduğu saptanmıştır. Periyodik bacak hareketleri olanların \%85.3'ünde uyku kalitesinin kötü olduğu belirlenmiştir (33).

HBS'li olan kadınların Yaşam Kalitesi Ölçeği'nden elde ettikleri puanların ortalamalarının (19 \pm 3.62$)$, HBS'li olmayanlara

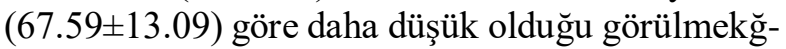
tedir. Ortalamalar arasında gözlenen bu fark istatistiksel olarak da anlamlı bir farklılaşmaya neden olmuştur. Başka bir ifadeyle, HBS'li olan kadınların yaşam kalitesinin, HBS'li olmayanlara göre daha kötü olduğunu söylemek istatistiksel olarak mümkündür $(\mathrm{p}<0.05)$. Literatür taramasında menopoz döneminde huzursuz bacak sendromu yaşayan kadınların yaşam kalitelerini irdeleyen herhangi bir çalışmaya rastlanmamıştır. Ancak menopoz dönemindeki kadınların yaşam kalitelerini inceleyen çalışmalarda kadınların çoğunluğunun yaşam kalitesi puanının orta düzeyde olduğu bulunmuştur (34).

HBS'li olan kadınların Fiziksel Fonksiyon alt boyutundan elde ettikleri puanların ortalama-

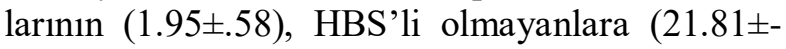
6.14) göre daha düşük olduğu belirlenmiş-tir. Ayrıca Fiziksel-Rol Sinırlamaları boyutunda da HBS'li olan kadınların ortalamalarının (1.34 \pm .44$)$ diğerlerine göre $(5.92 \pm 1.87)$ daha düşük olduğu ortaya çıkmıştır. Genel Sağlı Algısı alt boyutu incelendiğinde de; benzer bir bulguya rastlanmış ve HBS'li olan kadınların ortalamalarının (2.83 \pm .54$)$, HBS'li olmayanlara $(5.88 \pm 1.22)$ göre daha düşük olduğu belirlenmiştir. Enerji ve Zindelik alt boyutunda HBS'li olan kadınların ortalamalarının

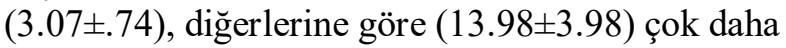
düşük değerler alması dikkat çekici bir bulgudur. Sosyal Fonksiyonellik ve Mental-Rol alt boyutları 
HBS'li olan kadınların ortalamalarının, HBS'li olmayanlara göre daha düşük olduğu diğer alt boyutlardır. Yaşam Kalitesi Ölçeği Parametreleri içerisinde Ağrı alt boyutunda, HBS'li olan kadınların ortalamalarının (7.66 \pm 1.41$)$, HBS'li olmayanlara (3.09 \pm 2.92$)$ göre daha yüksek olduğu dikkat çekmiştir. Benzer bir sonuç Ruh Sağlığı alt boyutunda ortaya çıkmış ve HBS'li olan kadınların ortalamalarının (2.19 \pm 1.51$)$, HBS'li olmayanlara $(0.31 \pm 1.63)$ göre daha yüksek olduğu belirlenmiştir. Söz konusu bu farkl1lıkların istatistiksel olarak anlamlı olup olmadığ incelendiğinde, sadece Ruh sağlığ 1 alt ölçeğinde iki grup arasında anlamlı bir farklılık görülmemiştir ( $>>0.05)$. Yaşam Kalitesi Ölçeği'nin fiziksel fonksiyon, fiziksel-rol sınırlamaları, ağrı, genel sağlık algısı, enerji ve zindelik, sosyal fonksiyonellik ve mentalrol alt ölçeklerinde istatistiksel anlamlılık düzeyinde farklılıklar olduğu ortaya çıkmıştır $(p<0.05)$. Literatür incelendiğinde; elde edilen bazı bulguların araştırma sonuçlarımızı destekler nitelikte olduğu belirlenmiştir. Taylor ve Gjevre tarafından yapılan çalışmada HBS şiddetinin yaşam kalitesini, sosyal fonksiyonu ve emosyonel iyilik halini de etkilediği bildirmişlerdir (35). McCrink ve arkadaşları yaptıkları çalışmada, semptomların özellikle geceleri daha şiddetli olduğunu, hastalığın günlük yaşamı etkilediğini bildirmişler ve hastalık şiddeti arttıkça yaşam kalitesinin bozulduğunu gözlemlemişlerdir (36). Gökçal ve arkadaşları tarafindan yapılan çalışmada HBS olgularında HBS olmayanlara göre yaşam kalitesinin düşük olduğu ve bu farkın özellikle ağrı, sosyal fonksiyon, fiziksel fonksiyon ve toplam fiziksel sağlık alanlarında belirginleştiğini belirtmişlerdir (37).

\section{Araştırmanın Sınırlılıkları}

$\mathrm{Bu}$ araştırma tek bir hastanede yapılmış olup elde edilen veriler katılımciların veri toplama formu ve ölçekleri değerlendirirken bulundukları bireysel beyanları ile sinırlıdır.

\section{Sonuç ve öneriler}

Çalışma sonuçlarımızda; kadınların yarısına yakınının (\%41.6) HBS tanı kriterlerini karşıladığı, \%57.2'sinni kötü uyku kalitesine sahip olduğu ve HBS'li olmayan kadınların yaşam kalitesinin HBS'li olan kadınlara göre daha iyi olduğu bulunmuştur. HBS, toplumda sik görülen bir hastalıktır. Menopozal dönemindeki kadınların toplumda halen yeterince bilinmeyen ve yaşam kalitesini olumsuz etkileyebilen Hbs açısından değerlendirilmesi faydalı olacaktır. Özellikle kadınların kaliteli bir yaşam sürmelerini sağlayacak menopozal dönemde yaşanan sorunlarla sağlıklı baş etme yolları kullanmaları ve menopozal dönemde yaşadıkları sıkıntıları tedavi eden hizmetlerinin yaygınlaştırılması, prevalansının tespiti için daha geniş örneklemli toplum tabanlı çalışmalara ağırlık verilmesi ve bu konuda hemşire ve ebelerin bu alanlarında uzmanlaşarak aktif rol almaları önerilmektedir.

\section{Kaynaklar}

1. World Health Organization The World Health Report 2003; Life in the 21st Century-a Vision for All. Geneva, Switzerland: WHO 2003.

2. Mishra G, Kuh D. Perceived Change in Quality of Life During the Menopause. Social Science \& Medicine 2006 62: 93-102.

3. Atasü T. Menopoz-tedavisi ve kanser'de: Atasü $\mathrm{T}$ (Editör). Menopoz: Tanım ve Terminoloji, İstanbul: Nobel Tip Kitabevleri; 2001.

4. Hacettepe Üniversitesi Nüfus Etütleri Enstitüsü. Türkiye Nüfus ve Sağlık Araştırması 2013, Ankara: Hacettepe Üniversitesi Nüfus Etütleri Enstitüsü, Sağlık Bakanlığı Ana Çocuk Sağlığı ve Aile Planlaması Genel Müdürlüğü, Başbakanlık Devlet Planlama Teşkilatı Müsteşarlığı ve TÜBİTAK, 2014.

5. Görgel EB, Çakıroğlu FP. Menopoz Döneminde Kadın. Ankara, Ankara Üniversitesi Basımevi, 2007.

6. Willis T. The London Practice of physick.1st ed, London, Basset ve Crookee; 1685.

7. Ekbom KA. Restless legs. Acta Med Scand 1945 158:1-123.

8. Hening W, Allen RP, Tenzer P, Winkleman JW. Restless legs syndrome: Demographics, presentation and differetial diagnosis, Geriatrics 2007 62: 26-9.

9. Phillips B, Young T, Finn L, Asher K, Hening WA, Purvis C. Epidemiology of restless legs symptoms in adults. ArchIntern Med 2000 160: 2137-2141.

10. Yüksel G, Varlıbaş F, Karlıkaya G, Tireli H. Huzursuz bacak sendromu: klinik ve 
demografik değerlendirme, Parkinson Hastalığı ve Hareket Bozuklukları Dergisi 2006 9:92-103.

11. Spiegelhalder K, Hornyak M. Restless legs symptoms in older adults, Clin Geriatr Med 2008 24:167-180.

12. Taşkın L. Doğum ve Kadın Hastalıkları Hemşireliği, 10. Bask1. Ankara Ofset Maatbacilik, 2011.

13. Berger K, Luedemann J, Trenkwalder C, John U, Kessler C. Sexandthe risk of restless legs syndrome in the general population, Arch Intern Med 2004 164(2):196-202.

14. Allen RP, Walters AS, Montplaisir J, Hening W, Myers A, Bell TJ, et al. Restless Legs syndrome prevelans and impact: Rest General Population Study, Arch Intern Med 2005 165:1286-92.

15. Üstün Y, Çınar Yücel Ş. Hemşirelerin uyku kalitesinin incelenmesi, Maltepe Üniversitesi Hemşirelik Bilim ve Sanatı Dergisi 2011 4:30-38.

16. Benbir G, Kaynak D, Kaynak H. Huzursuz bacak sendromu ve uykuda periyodik hareket bozukluğu, Türk Noroloji Dergisi 2004 10:117-123.

17. Onat ŞŞ, Delialioğlu SÜ, Biçer S, Özel S. Osteoporozda uykunun yaşam kalitesine etkisi. Türk Osteoporoz Dergisi 2013 19: 327.

18. Ghorayeb I, Bioulac B, Scribans C, Tison F. Perceived severity of restless legs syndrome across the female life cycle. Sleep Med 2008 9:799-802.

19. Montplaisir J, Denesle R, Petit D. Pramipexole in the treatment of restless legs syndrome: A follow-up study (in processcitation), Eur J Neurol. 2000;7: 27.

20. Agargün MY, Kara H, Anlar O. Pittsburgh uyku kalitesi indeksinin geçerliği ve güvenirliği. Türk Psikiyatri Dergisi 1996 7:107-15.

21. Ware JE, Sherbourne CD. The MOS 36-Item short-form health survey1: conseptual framework and item selection. MedicalCare 1992 30:473-483.

22. Koçyiğit H, Aydemir Ö, Fişek G, Ölmez N, Memiş A. Kısa Form-36 (KF-36)' nın Türkçe versiyonunun güvenirliği ve geçerliği, İlaç ve Tedavi Dergisi 1999 12:102-106.
23. Högl B, Kiechl S, Willeit J, Saletu M, Frauscher B, Seppi K, Müller J, Rungger G, Gasperi A, Wenning G, Poewe W. Restless legs syndrome: a community-based study of prevalence, severity, and risk factors, Neurology $200564: 1920-4$.

24. Taşdemir M, Erdoğan H, Boru UT, Dilaver E, Kumaş A. Epidemiology of Restless Legs Syndrome in Turkish adults on the western Black Seacoast of Turkey: A door-todoorstudy in a rural area, Sleep Med 2010 11:82-6.

25. Cho YW, Shin WC, Yun CH, Hong SB, Kim $\mathrm{JH}$, Allen RP, et al. Epidemiology of Restless Legs Syndrome in Korean adults, Sleep2008 31:219-23.

26. Turjanski N, Lees AJ, Brooks DJ. Striatal dopaminergic function in restless legs syndrome: 18F-dopa and 11C-raclopride PET studies. Neurology1999 52:932-7.

27. Deveci SE, Deveci F, Kırkıl G, Ulaş Ç. Sağlı çalışanlarında huzursuz bacak sendromu sıklığı, Kocatepe Tip Dergisi (Kocatepe MedicalJournal) 2012 13: 139148.

28. Winkelmann, J, Muller-Myhsok B, Wittchen HU, Hock B, Prager M, Pfister H, Strohle A, Eisensehr I, Dichgans M, Gasser T, Trenk walder C. Complex segregation analysis of restless legs syndrome provides evidence for an autosomal dominant mode of inheritance in early age at onset families. AnnNeurol 2002 52: 297-302.

29. Khan FH, Ahlberg CD, Chow CA, Shah DR, Koo BB. Iron, dopamine, genetics, andhormones in the pathophysiology of restless legs syndrome, J Neurol 2017.

30. Çölbay M. Huzursuz bacak sendromlu hemodiyaliz hastalarında uyku kalitesi, Genel Tip Dergisi 2007 17: 35-41.

31. Kim KW, Yoon IY, Chung S, et al. Prevalence, comorbiditiesand risk factors of restless legs syndrome in the Korean elderly population results from the Korean Longitudinal Study on Health and Aging, J Sleep Re 2010;19:87-92.

32. Phillips B, Hening W, Britz P, Mannino D. Prevalence and correlates of restless Legs Syndrome: results from the 2005 National Sleep Foundation Poll, Chest2006 129:7680. 
33. Güzel S, Kurtcebe ZÖ, Şencan S, Turhan N. Doğurganlık çağındaki kadınlarda hormonal değişikliklerin huzursuz bacak sendromu şiddeti, uyku ve yaşam kalitesi üzerine etkisi, Türk Fiz Tıp RehabDerg 2013 59:4551.

34. Kharbouch SB, Şahin NHB. Öenopozal dönemdeki yaşam kalitesinin belirlenmesi. İstanbul Üniversitesi F.N.H.Y.O. Dergisi 2007 15: 82-97.

35. Taylor-Gjevre RM, Gjevre JA, Skomro R, Nair B. Restless legs syndrome in a Rheumatoid arthritis patient cohort. J Clin Rheumatol, 2009 15:12-15.

36. McCrink L, Allen RP, Wolowacz S, Sherrill B, Connolly M, Kirsch J. Predictors of health-related quality of life in sufferers with restless legs syndrome: a multi-national study. Sleep Med 2007 8:73-83.

37. Gökçal E, Gür VE, Selvitop R, Babacan Yıldız G, Asil T, İdiyopatik Parkinson Hastalığında Motor ve Non-motor Semptomlar ve Yaşam kalitesine Etkileri, Arch Neuro psychiatr 2016 54:143-148. 